\title{
PENGARUH KOMUNIKASI, KOMPENSASI DAN LINGKUNGAN KERJA FISIK TERHADAP KINERJA TENAGA KEPENDIDIKAN DI LINGKUNGAN STIE BIITM SAHID BALI
}

\author{
I Wayan Astawa \\ STIE BIITM SAHID BALI \\ wyastawa@yahoo.co.id
}

\begin{abstract}
Abstrak
Penelitian ini dilakukan di STIE BIITM Sahid Bali dengan melihat pengaruh komunikasi, kompensasi dan lingkungan fisik terhadap kinerja tenaga kependidikan di dalamnya. Penelitian menggunakan data kuantitatif dengan mengukur dari kriteria komunikasi, kompensasi, dan lingkungan fisik. Data akan dianalisis secara kuantitatif dengan analisis korelasi berganda, regresi linier berganda, determinasi, uji signifikansi simultan dan parsial. Terdapat pengaruh secara simultan yang signifikan dari komunikasi, kompensasi dan lingkungan kerja fisik terhadap kinerja tenaga kependidikan di STIE BIITM SAHID BALI Ini dapat dilihat dari hasil koefisien korelasi berganda diperoleh adalah 0,852 dan F-hitung 34,769 lebih besar dari F-tabel 2,70 berarti berada pada daerah pernolakan Ho, maka Ho ditolak atau $\mathrm{H}_{\mathrm{i}}$ diterima. pengaruh yang positif dan signifikan, baik secara parsial maupun simultan antara komunikasi, kompensasi dan lingkungan kerja fisik terhadap kinerja tenaga kependidikan di STIE BIITM SAHID BALI, variabel-variabel tersebut tetap dipertahankan dan bila memungkinkan untuk ditingkatkan misalnya dengan menerapkan komunikasi yang lebih efektif, meningkatkan kompensasi jika keuangan perusashaan memungkikan dan memprogramkan perbaikan lingkungan kerja fisik.

Kata kunci: komunikasi, kompensasi, lingkungan fisik, kinerja
\end{abstract}

\begin{abstract}
This research was conducted at STIE BIITM Sahid Bali by looking at the effect of communication, compensation and the physical environment on the performance of the teaching staff in it. The study used quantitative data by measuring the communication criteria, compensation, and physical environment. Data were analyzed quantitatively by multiple correlation analysis, multiple linear regression, determination, simultaneous and partial significance tests. There is a significant simultaneous effect of communication, compensation and physical work environment on the performance of teaching staff in STIE BIITM SAHID BALI This can be seen from the results of the multiple correlation coefficient obtained is 0.852 and F-count 34.769 is greater than F-table 2.70 means it is located in the Ho reign area, then Ho is rejected or Hi is accepted. positive and significant influence, both partially and simultaneously between communication, compensation and the physical work environment on the performance of the teaching staff at STIE BIITM SAHID BALI, these variables are maintained and if possible to be improved for example by applying more effective communication, increasing compensation if corporate finance enables and programs improvements to the physical work environment.
\end{abstract}

Keywords: communication, compensation, physical environment, performance

\section{PENDAHULUAN}

Keberhasilan suatu organisasi dalam mencapai tujuan, salah satunya tergantung pada keahlian pimpinan mengelola dan melaksanakan fungsi organisasi seperti fungsi produksi, personalia, pemasaran dan sumber daya manusia. Kerja sama di antara fungsi-fungsi ini sangat diperlukan dalam rangka mencapai tujuan tersebut. Khusus untuk fungsi sumber daya manusia, pimpinan lembaga dituntut untuk mampu memenuhi kebutuhan hidup dari sumber daya manusianya.

Berkaitan dengan hal tersebut, manusia sebagai faktor utama dalam setiap kegiatan 
organisasi termasuk lembaga pemerintahan merupakan aset yang unik, karena dalam pengelolaannya begitu banyak faktor yang mempengaruhinya dan sangat sulit untuk diprediksi, hal tersebut tentunya akan mempengaruhi pencapaian kinerja dari setiap individu pegawai. Kinerja pegawai adalah prestasi kerja atau hasil kerja (output) baik kualitas maupun kuantitas yang dicapai pegawai dalam melaksanakan tugas kerjanya sesuai dengan tanggung jawab yang diberikannya. Selain itu, kinerja merupakan perilaku nyata yang ditampilkan setiap orang sebagai prestasi kerja yang dihasilkan oleh pegawai sesuai dengan perannya dalam suatu lembaga. Robbins (2006) menyatakan bahwa tenaga kependidikan yang memiliki kinerja yang baik akan selalu loyal dan memandang pekerjaannya sebagai hal yang menyenangkan, sedangkan tenaga kependidikan yang memiliki kinerja yang tidak baik akan melihat pekerjaannya sebagai sesuatu yang membosankan sehingga tenaga kependidikan tersebut bekerja dalam keadaan terpaksa.

Kompensasi adalah semua pendapatan yang berbentuk uang, barang langsung atau tidak langsung yang diterima tenaga kependidikan sebagai imbalan atas jasa yang diberikan kepada lembaga (Hasibuan, 2007 : 117). Kompensasi merupakan apa yang diterima oleh para tenaga kependidikan sebagai kontribusi mereka kepada organisasi. Kompensasi adalah balas jasa yang diberikan oleh lembaga kepada tenaga kependidikan, yang dapat dinilai dengan uang dan cenderung diberikan secara tetap (Simamora, 2007 : 448).

Meskipun lembaga sudah memberikan kompensasi finansial tetapi tenaga kependidikan masih mengeluh, dikarenakan kompensasi yang diberikan dirasa kurang mencukupi, terlebih tenaga kependidikan tidak mendapatkan uang transportasi yang dirasa semakin mahal akibat kenaikan bahan bakar minyak. Hal ini menyebabkan tenaga kependidikan kurang termotivasi sehingga menyebabkan penurunan kinerja.

Selanjutnya yang berpengaruh terhadap kinerja tenaga kependidikan adalah lingkungan kerja fisik. Swastha (2007 : 26) menyatakan bahwa lingkungan kerja fisik lembaga dapat diartikan sebagai keseluruhan faktor-faktor yang dapat mempengaruhi kinerja tenaga kependidikan dalam rangka pencapaian tujuan lembaga ataupun organisasi.

Kondisi lingkungan kerja fisik mengalami permasalahan, diantaranya adalah kebisingan suara sering kali menjadi masalah yang diakibatkan karena adanya lalu-lintas kendaraan di jalan raya. Ruang kerja tenaga kependidikan seperti bagian operator yang relatif sempit, sehingga mengurangi kebebasan tenaga kependidikan dalam bergerak. Kondisi locker bagi tenaga kependidikan sangat sempit, dimana hanya ada satu ruangan untuk locker yang diperuntukkan bagi seluruh tenaga kependidikan, sehingga saat tenaga kependidikan berganti pakai kerja, penuh sesak. Dalam hal ini penulis mencoba membuat suatu kajian terkait tentang komunikasi, kompensasi dan lingkungan fisik terhadap kinerja tenaga kependidikan yang 
ada di lingkungan STIE BIITM Sahid Bali dilihat dari berbagai teori penunjang yang ada dan konidis yang terdapat di lapangan.

\section{METODE PENELITIAN.}

Penelitian ini dilaksanakan pada STIE BIITM Sahid Bali yang beralamat di Jalan Buluh Indah No. 95 Denpasar. Alasan yang melatarbelakangi diadakannya penelitian di tempat ini adalah karena lembaga sedang giat-giatnya meningkatkan kinerja tenaga kependidikan sehingga diambil kebijakan dengan menerapkan komunikasi, pemberian kompensasi dan memperhatikan lingkungan.

Jenis data yang digunakan adalah data kuantitati yaitudata yang berbentuk angka-angka seperti jumlah tenaga kependidikan, jumlah hari kerja per bulan tingkat absensi dan kompensasi seperti : gaji pokok, uang makan danbonus.dan data kualitatif adalah data yang tidak dapat dihitung atau data yang bukan berupa angka-angka melainkan uraian-uraian seperti gambaran umum lembaga, struktur organisasi dan deskripsi kerja.

\section{Metode Pengumpulan Data}

1. Observasi

2. Wawancara

3. Studi dokumentasi

4. Koesioner

\section{Teknik Analisis Data}

1. Analisasi Kuantitatif

a. Analisis korelasi berganda

b. Analisis regresi linier berganda

c. Analisis Determinisasi

d.Uji Signifikansi Simultan (Uji Statistik

e.Uji Signifikansi Parsial (Uji Statistik t)

2. Analisis Kuantatif.

\section{HASIL DAN PEMBAHASAN}

\subsection{Kerangka Pemikiran Pengaruh Komunikasi, Kompensasi dan Lingkungan Kerja Fisik terhadap Kinerja Tenaga Kependidikan}




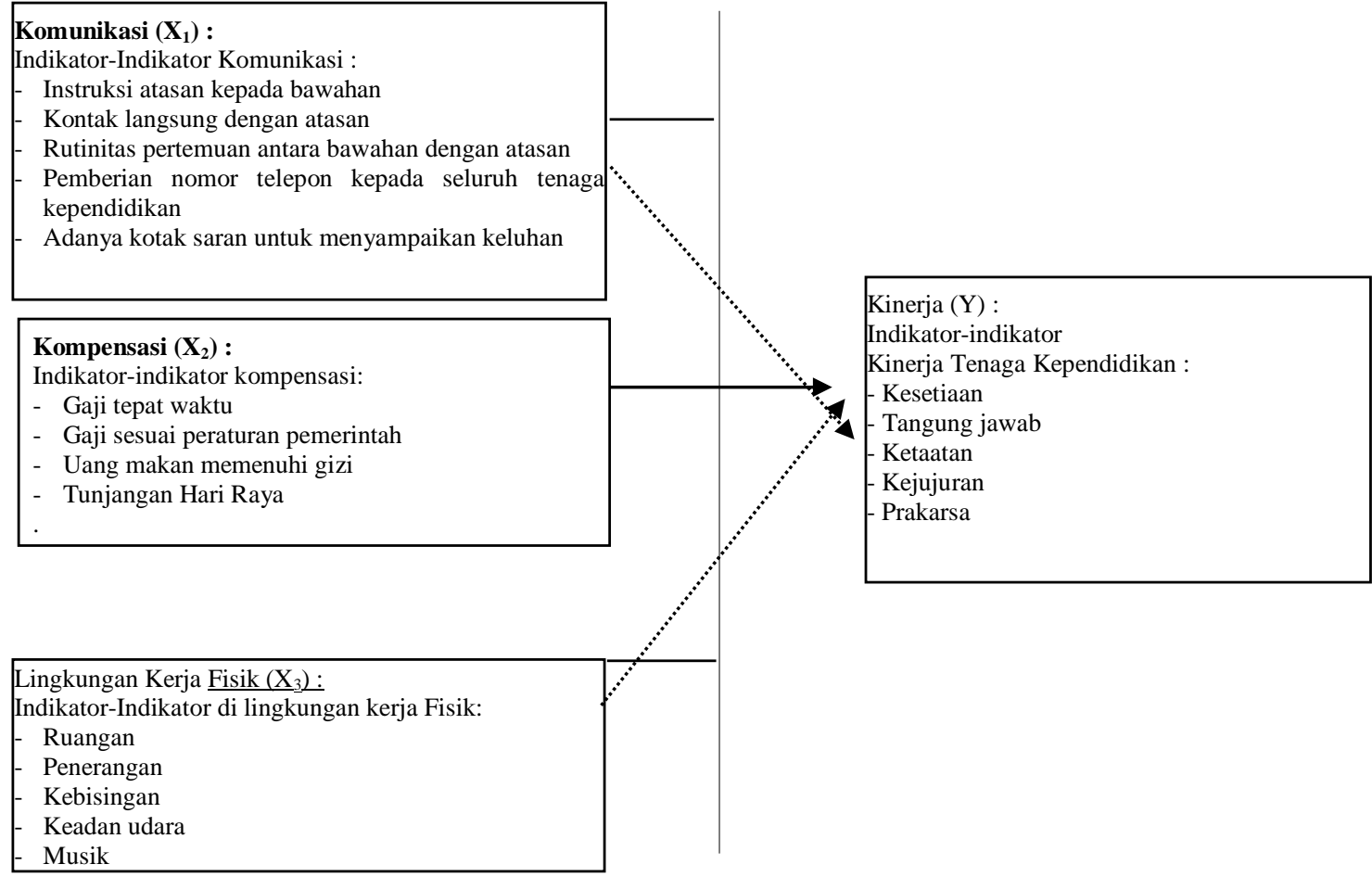

\subsection{Analisis Data}

\section{Analisis Korelasi Berganda}

Analisis ini digunakan untuk mengetahui hubungan secara simultan antara komunikasi, kompensasi dan lingkungan kerja fisik terhadap kinerja tenaga kependidikan. Hasil perhitungan koefisien korelasi berganda (R) di atas adalah 0,852 berarti terdapat korelasi yang sangat kuat secara positif atau searah dan signifikan secara simultan antara komunikasi, kompensasi dan lingkungan kerja fisik terhadap kinerja tenaga kependidikan. Hubungan positif menjelaskan adanya hubungan searah yaitu apabila komunikasi, kompensasi dan lingkungan kerja fisik secara simultan meningkat, maka akan diikuti oleh meningkatnya kinerja tenaga kependidikan.

\section{Analisis Regresi Linier Berganda}

Analisis ini digunakan untuk mengetahui pengaruh simultan antara komunikasi, kompensasi dan lingkungan kerja fisik terhadap kinerja tenaga kependidikan serta untuk mengetahui variabel mana diantara komunikasi, kompensasi dan lingkungan kerja fisik yang paling besar pengaruhnya terhadap kinerja tenaga kependidikan di STIE BIITM SAHID BALI Regresi linier berganda dinyatakan dalam bentuk persamaan garis regresi berganda dengan persamaan umum : 
$\mathrm{Y}=\mathrm{a}+\mathrm{b}_{1} \mathrm{X}_{1}+\mathrm{b}_{2} \mathrm{X}_{2}+\mathrm{b}_{3} \mathrm{X}_{3}+\mathrm{e}$

Dimana :

$\mathrm{Y}=$ Kinerja tenaga kependidikan

a = Nilai konstanta

$\mathrm{X}_{1}=$ Komunikasi

$\mathrm{X}_{2}=$ Kompensasi

$\mathrm{X}_{3}$ = Lingkungan kerja fisik

$\mathrm{b}_{1}=$ Koefisien regresi dari komuniksi $\left(\mathrm{X}_{1}\right)$

$\mathrm{b}_{2}=$ Koefisien regresi dari kompensasi

$\left(\mathrm{X}_{2}\right)$

$\mathrm{b}_{3}=$ Koefisien regresi dari lingkungan kerja fisik $\left(\mathrm{X}_{3}\right)$ Hasil perhitungan diperoleh hasil :

$$
\begin{aligned}
& \mathrm{a}=4,487 \\
& \mathrm{~b}_{1}=0,291 \\
& \mathrm{~b}_{2}=0,301 \\
& \mathrm{~b}_{3}=0,192
\end{aligned}
$$

Dengan demikian, dapat dinyatakan bahwa ada pengaruh yang positif atau searah secara simultan antara komunikasi, kompensasi dan lingkungan kerja fisik terhadap kinerja tenaga kependidikan atau dengan kata lain meningkatnya kinerja tenaga kependidikan dipengaruhi oleh meningkatnya komunikasi, kompensasi dan lingkungan kerja fisik secara simultan atau serempak, dimana pengaruh kompensasi lebih besar dibandingkan dengan pengaruh komunikasi dan lingkungan kerja fisik terhadap kinerja tenaga kependidikan.

\section{Analisis Determinasi}

Analisis ini digunakan untuk mengetahui variasi hubungan secara simultan antara komunikasi, kompensasi dan lingkungan kerja fisik terhadap kinerja tenaga kependidikan yang dinyatakan dalam prosentase dengan rumus $\mathrm{D}=\mathrm{R}^{2} \times 100 \%$. Besarnya $\mathrm{R}^{2}$ dapat diperoleh dari besarnya $R$ Square pada lampiran 8, yang besarnya 0,726. Maka :

$$
\begin{aligned}
D & =R^{2} \times 100 \% \\
& =0,726 \times 100 \% \\
D & =72,6 \%
\end{aligned}
$$

Hasil perhitungan diperoleh koefisien determinasi adalah $72,6 \%$ berarti secara simultan antara komunikasi, kompensasi dan lingkungan kerja fisik terhadap kinerja tenaga kependidikan sebesar 72,6\%, sedangkan sisanya sebesar $27,4 \%$ ditentukan oleh variabel lain diluar komunikasi, kompensasi dan lingkungan kerja fisik terhadap kinerja tenaga kependidikan yang tidak dibahas dalam penelitian ini. F-test digunakan untuk menguji signifikansi koefisien korelasi berganda (R) sehingga diketahui apakah hubungan secara simultan antara komunikasi, kompensasi dan lingkungan kerja fisik berpengaruh signifikan terhadap variabel terikat kinerja tenaga kependidikan di STIE BIITM SAHID BALI. Hasil perhitungan pada tabel 5.6 didapat Fhitung sebesar 34,769 dengan sig 0,000, ini berarti terdapat pengaruh yang signifikan secara simultan dari komunikasi, kompensasi dan lingkungan kerja fisik di STIE BIITM SAHID BALI.

\section{Uji Signifikansi Parameter Individual} (Uji Statistik t) 
Uji ini digunakan untuk menguji signifikansi masing-masing koefisien regresi, sehingga diketahui adakah pengaruh secara parsial antara komunikasi, kompensasi dan lingkungan kerja fisik terhadap kinerja tenaga kependidikan. Apakah pengaruh tersebut memang nyata terjadi (signifikan) atau hanya diperoleh secara kebetulan. Dengan menggunakan langkah-langkah pengujian hipotesis di atas, maka akan dijelaskan satupersatu pengaruh secara parsial dari masingmasing variabel terikat :

1) Pengaruh komunikasi $\left(X_{1}\right)$ terhadap kinerja tenaga kependidikan (Y)

Perhitungan pada tabel 5.6 menunjukkan bahwa koefisien beta komunikasi ( $\left.\mathrm{X}_{1}\right)$ didapat sebesar 0,281 , artinya secara parsial terdapat pengaruh sebesar 0,281 antara komunikasi dengan kinerja tenaga kependidikan di STIE BIITM SAHID BALI Adanya pengaruh yang signifikan tersebut ditunjukkan dengan hasil perhitungan t-hitung sebesar 3,483 dengan sig. 0,001 lebih kecil dari $\alpha=5 \%$. Koefisien beta didapat sebesar 0,281 artinya setiap terjadi peningkatan komunikasi sebesar satu satuan maka akan diikuti oleh peningkatan kinerja tenaga kependidikan sebesar 0,281 satuan.

2) Pengaruh kompensasi $\left(\mathrm{X}_{2}\right)$ terhadap kinerja tenaga kependidikan (Y)
Perhitungan pada tabel 5.6 menunjukkan bahwa koefisien beta kompensasi $\left(\mathrm{X}_{2}\right)$ didapat sebesar 0,348 , artinya secara parsial terdapat pengaruh sebesar 0,348 antara kompensasi dengan kinerja tenaga kependidikan di STIE BIITM SAHID BALI Adanya pengaruh yang signifikan tersebut ditunjukkan dengan hasil perhitungan thitung sebesar 3,775 dengan sig. 0,000 lebih kecil dari $\alpha=5 \%$. Koefisien beta didapat sebesar 0,348 artinya setiap terjadi peningkatan kompensasi sebesar satu satuan maka akan diikuti oleh peningkatan kinerja tenaga kependidikan sebesar 0,348 satuan.

3) Pengaruh lingkungan kerja fisik $\left(X_{3}\right)$ terhadap kinerja tenaga kependidikan (Y)

Perhitungan pada tabel 5.6 menunjukkan bahwa koefisien beta lingkungan kerja fisik $\left(\mathrm{X}_{3}\right)$ didapat sebesar 0,264, artinya secara parsial terdapat pengaruh sebesar 0,264 antara lingkungan kerja fisik dengan kinerja tenaga kependidikan di STIE BIITM SAHID BALI Adanya pengaruh yang signifikan tersebut ditunjukkan dengan hasil perhitungan t-hitung sebesar 2,921 dengan sig. 0,004 lebih kecil dari $\alpha=$ $5 \%$. Koefisien beta didapat sebesar 0,264 artinya setiap terjadi peningkatan lingkungan kerja fisik sebesar satu 
satuan maka akan diikuti oleh peningkatan kinerja tenaga kependidikan sebesar 0,264 satuan.

Hasil uji statistik-t mendukung hipotesis kedua dari penelitian ini yaitu : "Komunikasi, kompensasi dan lingkungan kerja fisik secara parsial berpengaruh signifikan terhadap kinerja tenaga kependidikan di Nusa Dua STIE BIITM SAHID BALI adalah terbukti, bukan didapat secara kebetulan.

Berdasarkan koefisien regresi diperoleh koefisien regresi untuk komunikasi $\left(\mathrm{X}_{1}\right)$ sebesar 0,291, kompensasi $\left(\mathrm{X}_{2}\right)$ sebesar 0,301 dan lingkungan kerja fisik sebesar 0,192. Hal ini berarti kompensasi merupakan variabel berpengaruh dominan terhadap kinerja tenaga kependidikan pada STIE BIITM SAHID BALI karena memiliki koefisien regesi terbesar jika dibandingkan variabel komunikasi dan lingkungan kerja fisik.

\section{PENUTUP}

\section{Kesimpulan}

Bertitik tolak dari hasil analisis data dan pembahasan tersebut, maka didapat dirumuskan simpulan sebagai berikut :

1. Ada pengaruh secara simultan yang signifikan dari komunikasi, kompensasi dan lingkungan kerja fisik terhadap kinerja tenaga kependidikan di STIE BIITM SAHID BALI Ini dapat dilihat dari hasil koefisien korelasi berganda diperoleh adalah 0,852 dan F-hitung 34,769 lebih besar dari F-tabel 2,70 berarti berada pada daerah pernolakan Ho, maka Ho ditolak atau $\mathrm{H}_{\mathrm{i}}$ diterima. Ini berarti memang benar terdapat hubungan yang signifikan secara simultan antara komunikasi, kompensasi dan lingkungan kerja fisik terhadap kinerja tenaga kependidikan dan bukan diperoleh secara kebetulan.

2. Ada pengaruh secara parsial yang signifikan komunikasi, kompensasi dan lingkungan kerja fisik terhadap kinerja tenaga kependidikan pada STIE BIITM SAHID BALI Hasil t-test regresi diperoleh $\mathrm{t}_{1}$-hitung adalah sebesar $3,483, t_{2}$-hitung adalah sebesar 3,775, $t_{3-}$ hitung adalah sebesar 2,921, dimana dinilai thitung masing-masing variabel tersebut lebih besar dari t-tabel yaitu 1,698 berada pada daerah penolakan Ho, maka Ho ditolak dan $\mathrm{H}_{\mathrm{i}}$ diterima, berarti ada pengaruh positif dan nyata (signifikan) secara parsial antara komunikasi, kompensasi dan lingkungan kerja fisik terhadap kinerja tenaga kependidikan pada STIE BIITM SAHID BALI.

3. Kompensasi merupakan variabel yang berpengaruh dominan terhadap kinerja tenaga kependidikan pada STIE BIITM SAHID BALI Hal ini disebabkan karena kompensasi memiliki koefisien regresi terbesar yaitu 0,301, sedangkan variabel komunikasi sebesar 0,291 dan lingkungan kerja fisik sebesar 0,192 .

\section{Saran}

Berdasarkan simpulan tersebut di atas, maka dapat disarankan kepada manajemen di STIE BIITM SAHID BALI, antara lain: 
1. Mengingat terdapat maka pengaruh yang positif dan signifikan, baik secara parsial maupun simultan antara komunikasi, kompensasi dan lingkungan kerja fisik terhadap kinerja tenaga kependidikan di STIE BIITM SAHID BALI, variabel-variabel tersebut tetap dipertahankan dan bila memungkinkan untuk ditingkatkan misalnya dengan menerapkan komunikasi yang lebih efektif, meningkatkan kompensasi jika keuangan perusashaan memungkikan dan memprogramkan perbaikan lingkungan kerja fisik.

2. Mengingat masih terdapat faktor lain yang mempengaruhi kinerja tenaga kependidikan, maka pihak STIE BIITM SAHID BALI harus memperhatikan faktor-faktor lain seperti kepemimpinan, motivasi dan kompetensi, sehingga kinerja tenaga kependidikan bisa lebih ditingkatkan.

3. Oleh karena kompensasi merupakan variabel berpengaruh dominan terhadap kinerja tenaga kependidikan, maka sebaiknya STIE BIITM SAHID BALI tetap mempertahankan penerapan kompensasi dan dan meningkatkan komunikasi dan lingkungan kerja fisik agar lebih baik lagi.

\section{DAFTAR PUSTAKA}

Arikunto Suharsimi, 2006, Prosedur Penelitian Suatu Pendekatan Praktis, Penerbit Rineka Cipta, Jakarta.

Dharma Agus, 2007, Gaya Kepemimpinan Yang Efektif Bagi Manajer, Sinar Baru, Bandung.
Freddy Rangkuti, 2008, Business Plan, Gramedia Pustaka Utama, Jakarta.

Hasibuan SP. Malayu, 2007, Manajemen Sumber Daya Manusia, Edisi Revisi, Bumi Aksara, Jakarta.

Mangkunegara Anwar Prabu, 2009, Evaluasi Kinerja SDM, Penerbit Refika Aditama, Bandung.

Mangkunegara, A.A. Anwar Prabu, 2011,Manajemen Sumber Daya Manusia Lembaga. Bandung : Remaja Rosdakarya.

Manulang M, 2007, Manajemen Personalia, Aksara Baru, Jakarta.

Martoyo Susilo, 2008, Manajemen Sumber Daya Manusia, BPFE, Yogyakarta.

Priansa Donni Juni dan Garnida Agus, 2013, Manajemen Perkantoran (Efektif, Efisien dan Profesional),

Cetakan ke-1, Alfabeta, Bandung

Riduwan dan Sunarto, 2011, Pengantar Statistika Untuk Penelitian : Pendidikan, Sosial, Komunikasi, Ekonomi dan Bisnis, Alfabeta, Bandung.

Rivai Veithzal, 2008, Manajemen Sumber Daya Manusia Untuk Lembaga : dari Teori dan Praktik, PT. RajaGrafindo Persada, Jakarta.

Sedarmayanti, 2009,Manajemen Sumber Daya Manusia, Reformasi Birokrasi dan Manajemen Pegawai Negeri Sipil. Cetakan Pertama. Bandung : PT. Refika Aditama

Sugiyono, 2012, Statistika Untuk Penelitian, Cetakan Ke-21, Penerbit CV. Alfabeta, Bandung.

Sunyoto Danang dan Burhanudin, 2011, Perilaku Organisasi, Cetakan 1, CAPS, Yogyakarta.

Sutrisno Edy, 2009, Manajemen Sumber Daya Manusia, Edisi Pertama, Penerbit : Pernada Media, Jakarta.

Swastha Basu, 2007, Azas-azas Marketing, Penerbit Liberty, Yogyakarta.

Utama Mudiartha, 2007, Manajemen Sumber Daya Manusia, Denpasar: Universitas Udayana.

Widjaja, H.A.W, 2010, Komunikasi dan Hubungan Masyarakat, Bumi Aksara, Jakarta. 